\title{
Compulsory Annuitisation: A Policy Option for Australia?
}

Taleitha O'Meara'1, Aaron Bruhn²

\begin{abstract}
The use of lifetime annuities is one obvious candidate to deliver guaranteed income in retirement. This paper quantifies the marginal increase in income to a single male when compelled to purchase a lifetime annuity from superannuation savings, compared to the current position of voluntary annuitisation in the Australian market. It is found that significant increases in average income are possible under compulsion, with an associated decrease in the cost of the age pension. Future mortality is shown to be the key area of sensitivity. The critical importance of future age pension eligibility rules being adaptable in line with mortality changes is demonstrated.
\end{abstract}

Keywords: Annuities; superannuation; compulsory annuitisation; retirement income; annuitization

JEL Classification: D14

\footnotetext{
1 taleitha_c@hotmail.com

2 Australian National University, aaron.bruhn@anu.edu.au
} 


\section{INTRODUCTION}

The Australian retirement income system consists of three major pillars:

1. A means-tested age pension that is financed from general taxation revenue;

2. A mandatory private retirement savings component with minimum employer contributions of $9 \%$ on a fully funded basis (the 'Superannuation Guarantee Charge $\left.(\mathrm{SGC})^{3}\right)$; and

3. A voluntary private retirement savings component with additional contributions made at the discretion of employers and/or individuals.

The lack of integration between the first two pillars has been identified as a major problem with the Australian system (Atkinson et al., 1999). This is particularly due to the availability of lump sum retirement benefits from superannuation savings and no compulsion for superannuation balances to be taken in a pension form.

The need for the SGC ("Pillar 2") arose due to the expected future social and economic implications of Australia's ageing population, which as for many developed and developing nations, is becoming an increasingly significant issue ${ }^{4}$. One implication is that the number of individuals expected to rely on some form of the age pension will increase considerably, and at the same time the number of individuals in the workforce to support funding of the age pension will decrease ${ }^{5}$. However by various measures the age pension in Australia provides only a modest income, and with many individuals expected to outlive their retirement savings, there is a growing need for retirees to protect themselves against the associated longevity ${ }^{6}$ and investment ${ }^{7}$ risks.

This paper quantifies, for a cohort of male workers employed full-time, the marginal increase in guaranteed income that would accrue as a result of being compelled to purchase a lifetime annuity from superannuation savings. It also quantifies potential financial implications of this compulsion on the provision of the age pension.

\section{SUPERANNUATION $^{8}$}

The introduction and subsequent increases in the SGC aimed to provide a means for individuals to fund their retirement in an effort to curb the effects of Australia's ageing population (IAAust, 2009), and the growth in superannuation coverage across the Australian

\footnotetext{
${ }^{3}$ The primary purpose of the SGC was to compel individuals to save in order to provide an adequate income for themselves during retirement (FaHCSIA, 2009). It was initially set at $3 \%$ of salary, with increases phased-in to reach a maximum of $9 \%$ in 2002/2003 (APRA, 2007). The recent Henry review and Australian governmental response in its 2010 budget has recommended a further phased increase to reach $12 \%$ by 2020 (Commonwealth, 2010).

${ }^{4}$ Population ageing is due to changes in fertility and mortality rates, both of which have been falling for more than a century (McDonald \& Kippen, 2004). It will contribute to substantial pressure on government spending over the next 40 years. Increases in health, aged care and age pension spending will increase from 7.5\% of GDP currently to $13.8 \%$ of GDP in 2050, which in 2009-10 dollars equates to a tripling of real spending per person (Treasury, 2010).

${ }^{5}$ By 2050 the number of Australia's population aged 65 to 84 will double, the number 85 and over will more than quadruple, and 23\% of the population will be aged 65 and older. The number of people in the potential workforce for every individual aged 65 and over will fall from 5 to 2.7 (Treasury, 2010).

${ }^{6}$ Longevity risk is the risk that retirement savings and investments may be inadequate to sustain the individual as a result of decreasing mortality over time.

${ }^{7}$ Investment risk is the risk that the individual's invested superannuation funds will not yield the returns required to provide an adequate income in retirement.

${ }^{8}$ In Australia the colloquial meaning of "superannuation" is distinct from that of a pension, where in general the former applies to pre-retirement savings and the latter applies to post-retirement income.
} 
population is testimony to the success and breadth of this public-policy intent. However, while superannuation balances are increasing as the system matures, average superannuation balances are below those anticipated when compulsory superannuation was introduced in 1992, including a number of groups with low levels of superannuation (Clare, 2007). Recent events such as the global financial crisis (GFC) compounds this issue, where Australia's superannuation funds experienced real losses of $26.7 \%$ in 2008, primarily due to the high proportion (57\%) of investments held in equities (OECD, 2009).

A continuing demand for further assistance to achieve a modest standard of living in retirement is likely, perhaps via the Commonwealth-provided age pension as well as further encouragement to save. The apparent separation of pre-retirement savings and postretirement planning compounds this issue as the savings an individual sees accruing throughout their working life is not placed in the context of what that could provide as a retirement income (guaranteed or otherwise).

\section{THE GOVERNMENT AGE PENSION}

The Commonwealth of Australia introduced a means-tested 'flat-rate' age pension that was financed from general tax revenue in July 1909, which was paid to men from age 65 and women from age 60, subject to a residency qualification (ABS, 1988). Changes to the pension eligibility age in Australia have only recently been agreed, with the pension eligibility age set at 67 for males from 2023 and 65 for females from $2014^{9}$ (Commonwealth, 2009).

Changes to eligibility criteria and subsequent levels of coverage have changed over time in line with cost pressures and political will. Approximately $60 \%$ of pensioners now receive the maximum rate of the age pension (OECD, 2009). Projections for 2047 reveal that the proportion of aged individuals receiving some form of the age pension is expected to remain at approximately 75\%; but increases in superannuation assets and income will reduce the proportion of pensioners receiving the full pension to 35\% (Treasury, 2007).

Age pension benefit rates were generally increased on an ad hoc basis until the 1970s, with consumer price index-related and wage growth-related increases implemented thereafter. In 1997 the single pension rate was benchmarked to at least $25 \%$ of the MTAWE ${ }^{10}$ (FaHCSIA, 2008). The overall result is that since 1970, the real value of the maximum single and couples pension rates has increased by approximately 200\% (FaHCSIA, 2008). More recently the single age pension was set to two-thirds of the age pension couple's rate (Commonwealth, 2009). However, the level of the single age pension ${ }^{11}$ is still below the level required to provide an adequate income for a single retiree according to various measures (see Table 1).

According to the OECD (2009), 27\% of Australians aged over 65 have incomes below the OECD poverty threshold. This figure is particularly high due to the relatively low level of income provided by Australia's age pension, which is estimated to be $20 \%$ less than equivalent schemes in other OECD countries ${ }^{12}$.

\footnotetext{
${ }^{9}$ This is despite the fact that life expectancy in Australia has increased from 55 to 79 years for men and from 59 to 83 years for women over the last century (ABS, 2008a).

${ }^{10}$ The MTAWE (All Males Total Average Weekly Earnings) index is produced by the Australian Bureau of Statistics to benchmark the level of male wages across the workforce (including full-time, part-time, casual and junior employees).

${ }^{11}$ For consistency of comparison to other measures, the 2009 figure of $\$ 17,555$ per annum is used.

${ }^{12}$ For example, the average annual benefit received by an age pensioner in Australia is equivalent to $23 \%$ of Australia's average earnings (US\$41,600), while for New Zealand the equivalent figure is $41 \%$ (OECD 2009).
} 
Table 1: Measures of Adequacy in Retirement (annual income)

\begin{tabular}{|c|c|}
\hline Adequacy Measure & Recommended Income \\
\hline Westpac ASFA Retirement Standard Modest Lifestyle ${ }^{13}$ & $\$ 19,533$ \\
\hline Westpac ASFA Retirement Standard Comfortable Lifestyle & $\$ 37,822$ \\
\hline OECD Poverty Threshold ${ }^{14}$ & $\$ 27,600$ \\
\hline Institute of Actuaries of Australia recommended replacement Rate ${ }^{15}$ & $\$ 38,640$ \\
\hline
\end{tabular}

\section{THE RETIREMENT INCOME MARKET}

Currently, allocated pension products account for more than $85 \%$ of the retirement income market (IFSA, 2007) ${ }^{16}$. However, one concern with these products is that they do not offer retirees complete protection against longevity and investment risks as they do not offer a guaranteed income ${ }^{17}$. Furthermore, with sudden falls in equity markets such as during the GFC, this sort of shock for an individual drawing down a retirement income from an allocated pension could be financially catastrophic.

The fact that an individual faces significant longevity and investment risks in providing an income throughout retirement is complicated further by the tendency of individuals to underestimate their life expectancy (Banks et al., 2004; O’Brien et al., 2005), as well as low levels of financial literacy, as demonstrated via several surveys (ANZ 2002, 2005, 2008; FLF 2007). It is also exacerbated by the implicit assumption within the preference for allocated pensions that retirees prefer to not have a guaranteed income in retirement. It seems peculiar that retirees are willing to take a risk that they may not have a derived income at some point, that they were not willing to take in the course of their working lives (for example, leaving a safe job and going into their own business for the sake of a higher income/return). This assumption or decision of greater risk taking in retirement against the backdrop of having less ability to do anything about it if things go wrong, compared to one's working life, appears to suggest that retirees are not well versed in the risks that they face with the status quo. As such a responsible policy focus should be increasingly on ensuring that retirement income can be sustained throughout an individual's life (AFR, 2009).

\section{ANNUITIES}

A range of annuity products are available across various markets. These include conventional, temporary, deferred, guaranteed (or term-certain), value-protected, participating, investment-linked and variable annuities. Each have differing characteristics which are well described in the literature (Cannon \& Tonks, 2008; Loh \& Gosden, 2007; MacDonald et al., 2011), and payments can be fixed in nominal terms ("level”), fixed in real terms ("inflation-indexed"), or increased at a pre-specified rate ("graded"). Of particular interest to the analysis in this paper is a conventional life annuity, which provides a periodic income for as long as the annuitant is alive.

\footnotetext{
${ }^{13}$ Westpac-ASFA (2009).

${ }^{14}$ Equal to half of the median household income (OECD, 2009).

${ }^{15}$ The Institute of Actuaries of Australia recommends a replacement rate of 70-80\% (IAAust 2002). The per annum income shown in the table is $70 \%$ of the median household income calculated by the OECD (2009).

${ }^{16}$ This is mainly due to tax exemption on their investment earnings, the range of investment options available and potential for high returns, with the only real restriction on the individual being that regular income withdrawals must reside within a specified range (IAAust, 2009).

${ }^{17}$ For example, for a male aged 60 with an account balance of \$360,000 and 30\% held in domestic equities as a proxy for growth assets, there is a $46 \%$ chance of allocated pension fund depletion before age 86 (Rawlinson \& Cater, 2008).
} 
The popularity of product types varies from market to market. For example, variable annuities are popular in the US; level annuities currently dominate the UK market; while over 90\% of annuities purchased in Singapore are deferred annuities (Fong 2002; Cannon \& Tonks, 2008; Lewis, 2009).

\section{Advantages}

A main advantage of purchasing a conventional life annuity over other retirement income products is the protection provided against longevity risk as an income for life is guaranteed. It also provides protection against investment risk by transferring this risk to the annuity provider. The theoretical result of Yaari (1965) demonstrated that complete annuitisation is optimal for a risk-averse individual facing an uncertain lifetime. Annuities are also the most financially efficient way of providing an income stream from capital due to the pooling of risk (DWP, 2002), although this only occurs if the annuitant population mortality is representative of the general population mortality.

\section{Lack of popularity}

Given that lifetime annuities are beneficial in alleviating risks to the individual in retirement, demand for annuities could be expected to be high - but in Australia this is not the case as few individuals choose to purchase lifetime annuities and the retirement income market is dominated by allocated pension products. Many reasons have been put forward to explain this state of affairs. The US Society of Actuaries recently released a research report (MacDonald et al., 2011) which provides a comprehensive list of reasons as to why annuities are not popular in markets where their purchase is voluntary, broken into three main categories (number of distinct reasons in brackets):

1. Rational decisions arising from personal preferences and circumstances (10);

2. Rational decisions arising from environmental limitations (7); and

3. Decisions arising from behavioural biases (17)

The reasons are not repeated here, but it is noted that most researchers agree that for a particular market, no one reason is adequate to explain the low demand ${ }^{18}$. Unsurprisingly, annuity markets flourish in countries that compel individuals to purchase annuities, such as in the $\mathrm{UK}^{19}$, but more surprising is that annuity sales only tend to flourish in these markets (Cannon \& Tonks, 2008).

\footnotetext{
18 Also, there are dependencies between different reasons, and many postulated reasons themselves have arguments against them being a significant factor, For example, one obvious reason to not purchase an annuity is the lack of bequest upon early death (this is a "rational decision arising from personal preferences"). This implies the individual sees the annuity purchase in an investment context (whereby annuities appear unattractive since there is a probability of losing a large amount upon 'early' death), rather than in an insurance context (viewing annuities positively as insurance that guarantees an income for life). This is “decision framing” (a "decision arising from behavioural biases"). However, evidence on the importance of bequest motivations is mixed: some studies claim that individuals consciously leave wealth to heirs (Bernheim, 1991; Laitner \& Juster, 1996; Wilhelm 1996), others find no evidence of bequest motives among the elderly (Hurd, 1987, 1989), others find that bequest motives have a trivial impact on the annuity decision (Brown et al., 2008), and Rowlingson and McKay (2005) conclude that whilst inheritance is considered important, it is not entrenched as either an expectation or a duty.

${ }^{19}$ It is compulsory in the UK for individuals to use a certain proportion of their pension funds to generate income. In 2007, 78\% of pension funds were converted into income streams through annuities, and the remaining 22\% were converted through products similar to Australia’s allocated pension (Lewis, 2009).
} 


\section{COMPULSION}

The view of the UK Treasury is that tax relief on pension contributions is solely provided so individuals can save for an income during retirement (HM Treasury, 2006). Thus for the Australian context, it is arguable that concessional tax on superannuation savings should be coupled to a retirement income provision that gives optimal outcomes at a collective ("pooled") level - in other words an annuity ${ }^{20}$. Therefore, compelling individuals to convert some or all of their superannuation balances into an annuity for the purposes of retirement income, is a policy option worthy of some consideration. The authors make no claim that this is the best approach, or a required one to optimise public policy goals, but the intent is simply to examine the implications if there were such a requirement.

Compulsion could mandate the purchase of an annuity from a portion of superannuation savings, with many possibilities regarding the form and substance that this could take. For example, a set percentage of savings could be annuitised, or a certain dollar value, or a combination subject to some minimums, maximums or relative size to the age pension. The relative worth of various combinations in itself is worthy of further discussion, but is not advanced here.

An obvious objection to compulsion is being told what to do with what is considered a personal asset. A response could be that many things relating to an individual's time and financial assets are already compelled because it is deemed beneficial at a societal level. For example, schooling is compulsory for certain ages, paying tax is also compulsory, as is the effective deferment of pay for one's work - otherwise known as the SGC. The potential to compel in the retirement phase is not necessarily a barrier too far, given the right case and appeal to the collective 'good'.

An expected advantage of compulsory annuitisation is that a more effective pooling of longevity risk will lead to a reduced price for annuities. This arises because mortality experience will reflect that of the general population as opposed to a 'select' population under voluntary annuitisation.

A retirement income system with some form of compulsory annuitisation may potentially be a way to ensure Australians use their superannuation balances for their intended purpose: to fund their retirement. This could also help relieve the increasing costs associated with funding the age pension, which is a major concern given the projected demographic changes for Australia. Hence, this is considered as the bridge between the availability of lump sum retirement benefits from superannuation savings, and the need to deliver post retirement income. The analysis in this paper explores this option in more detail.

\section{POLICY OPTIONS CONSIDERED}

Retirees are assumed to annuitise a minimum of $75 \%$ of their superannuation balance at retirement ${ }^{21}$. Retirement income is defined as the sum of the annuity payment arising from a purchase via superannuation balances at age 67, plus the resultant level of the age pension that an individual is entitled to. Changes in retirement income and the cost of the age pension are considered under a number of different policy options. These are as follows:

\footnotetext{
${ }^{20}$ Hence, it may be that approaches to annuitisation focus on different options for employer-provided versus voluntary superannuation components.

${ }^{21}$ Addressing longevity is a pressing issue, however flexibility in retirement is also important and as such partial annuitisation of superannuation balances was considered an appropriate trade-off. A partial annuitisation policy retains an incentive for voluntary superannuation contributions, and is likely to be straightforward to implement given that the policy applies the same rule across all individuals and so is likely to be considered 'fair', and arguably it partially addresses aversions to annuities stemming from bequest arguments.
} 
a. Voluntary annuity purchase;

b. Compulsory annuity purchase under private provision;

c. Compulsory annuity purchase under Government provision ${ }^{22}$; and

d. Compulsory annuity purchase under Government provision with revised meanstesting of the age pension

An individual in Australia is currently subject to both income and asset testing for the age pension, with the applicable pension rate being the lower one arising from these two tests. For policy options (a) - (c) ${ }^{23}$, the 2009 income and asset tests as per below were assumed to apply:

Table 2: Age Pension Income and Asset Tests, per annum

\begin{tabular}{|c|c|c|c|c|}
\hline & \multicolumn{2}{|c|}{ Income Test } & \multicolumn{2}{|l|}{ Asset Test } \\
\hline & $\begin{array}{l}\text { Free } \\
\text { threshold }\end{array}$ & $\begin{array}{l}\text { Part payment } \\
\text { cut-off }^{1}\end{array}$ & $\begin{array}{l}\text { Free } \\
\text { threshold }\end{array}$ & $\begin{array}{l}\text { Part payment } \\
\text { cut-off }^{2}\end{array}$ \\
\hline Homeowner & $\$ 3,692$ & $\$ 38,802$ & $\$ 178,000$ & $\$ 628,128$ \\
\hline Non-homeowner & $\$ 3,692$ & $\$ 38,802$ & $\$ 307,000$ & $\$ 757,128$ \\
\hline $\begin{array}{l}\text { Reduction in } \\
\text { pension } \\
\text { payments }\end{array}$ & \multicolumn{2}{|c|}{$\begin{array}{l}\text { Income over the free } \\
\text { threshold amount reduces } \\
\text { pension payments by } \$ 0.50 \\
\text { in the dollar. }\end{array}$} & \multicolumn{2}{|c|}{$\begin{array}{l}\text { Assets over the free threshold } \\
\text { amounts reduce pension } \\
\text { payments by } \$ 39 \text { per annum }{ }^{3} \\
\text { for every } \$ 1,000 \text { of assets over } \\
\text { the limit. }\end{array}$} \\
\hline
\end{tabular}

Source: Centrelink (2009), Commonwealth (2009)

${ }^{1}$ When only income is taken into consideration.

${ }^{2}$ When only assets are taken into consideration.

${ }^{3}$ According to the current penalty of $\$ 1.50$ per fortnight for every $\$ 1,000$ of assets over the limit.

For policy option (d), given the compulsion to purchase an annuity using $75 \%$ of superannuation funds, it is inappropriate to assess individuals against both income and asset tests. Hence policy option (d) assesses means-testing of the age pension according to an adjusted income test only, but strengthened to compensate for the removal of the assets test. The revised income test adopts a free threshold of $\$ 10,000$ above which any income, excluding employment income ${ }^{24}$, reduces pension payments by $\$ 0.85$ in the dollar. This implies a part pension payment cut-off of $\$ 30,653^{25}$.

\footnotetext{
${ }^{22}$ Government provision of annuities under compulsion is considered because it focuses the analysis on the effects of compulsion rather than additional conditions required to make compulsion happen via the private sector; it allows simplified assumptions to be made regarding expenses and profit requirements; and it mitigates concerns regarding the risk of institutional failure thus removing one reason for compulsion to not be supported. For philosophical and well considered reasons this option may be subject to some objection, but it is considered here nonetheless and is in line with recent suggestions that indicate that optimal efficiency of a compulsory arrangement may be achieved via Government provision (Sherris \& Evans, 2009).

${ }^{23}$ Also, options (a) - (c) assumed means-testing of annuities according to the current rules: individuals are only income tested on their 'assessable income', which is equal to annuity income minus an 'income deduction'; and the purchase price of an annuity is considered to be assessable under the assets test (Centrelink, 2009). The per annum 'income deduction' is calculated as the annuity purchase price divided by the life expectancy assumed in the pension system.

${ }^{24}$ One reason to exclude employment income from income testing is to encourage older individuals to remain in the workforce, which increases their income, alleviates the cost of the age pension through additional tax receipts, and potentially fulfils a role in relieving projected employment shortages (Treasury, 2007). This means that income earned from employment would be taxed at marginal taxation rates on personal income.

${ }^{25}$ This is equal to $10,000+17,555 / 0.85$.
} 


\section{METHODOLOGY}

All analysis is based upon projections for a male aged 30 in 2009, with the fact that the superannuation system is expected to be fully mature by 2037 (NATSEM, 2009) shaping this choice $^{26}$. Males are chosen due to their higher propensity to work full-time without breaks over their entire working lives, which suits the purposes of the projections that follow.

Under each policy option superannuation balances are projected to retirement, with a minimum of $75 \%$ then assumed to purchase an annuity. This amount is set equal to the expected present value $\left(\mathrm{EPV}^{27}\right)$ of a conventional life annuity of $\$ \mathrm{X}$ per year, after accounting for expenses, commission and profit margins. Solving for $\mathrm{X}$ gives the annual annuity payment. The present value of the resultant age pension is then also calculated at that age in order to determine overall income.

\section{Projection Of Superannuation Balances At Retirement}

The distribution of superannuation balances was projected out to age $67^{28}$. Individuals were assumed to work full-time and then retire at age 67, not drawdown their superannuation before then, and not make additional voluntary superannuation contributions ${ }^{29}$. The required assumptions for this projection are provided below in Table 3 (Appendix A provides further details).

The resulting estimates of nominal superannuation balances at age 67 (relating to the year 2046) were adjusted for general price inflation to obtain superannuation balances at retirement in 2009 dollars, for various point estimates. A regression was fitted to these point estimates to obtain an approximation for the distribution, between the $5^{\text {th }}$ and $95^{\text {th }}$ percentile, of superannuation balances. Details are provided in Appendix B. This distribution suggests that half of the male population retiring in 2046 (aged 67) will have superannuation balances of more than \$353,612 (in 2009 dollars).

\section{Projection Of Present Value Of The Age Pension}

To estimate the present value of age pension payments for a male aged 67 in 2046, various assumptions are required. These are provided in Appendix C. In particular, the full rate of the single age pension was assumed as $\$ 17,555$ per annum (Commonwealth, 2009), and because an estimate is sought in real dollars, a real (and risk-free) discount rate was used, in conjunction with age pension payments unadjusted for inflation.

To enable a wider canvassing of potential future outcomes, the present value of age pension payments were calculated under combinations of mortality rates relating to

\footnotetext{
${ }^{26}$ Of course, other demographic model points can be considered in future work, but the cohort of workers between the ages of 25 and 34 is the first cohort, for which data is available, to retire having received compulsory superannuation contributions of $9 \%$ over the whole of their working lives.

${ }^{27}$ An expected present value basis (also termed actuarial present value) accounts not only for the time value of money via the use of an appropriate discount rate, but also for the probability of future payment being impacted by mortality.

${ }^{28} 67$ is the age at which an individual will be eligible for the age pension from 2025 (Commonwealth, 2009), and it allows the determination of the interaction of annuity incomes with the age pension.

${ }^{29}$ All of these assumptions can of course be varied to match any combination of future employment and behavioural patterns, but this base case is established with future research left to consider a wider range of scenarios.
} 
improvements up to 2046, and improvements beyond $2046^{30}$. Table 3 shows the expected present value (EPV) of age pension payments for a male aged 67 in 2046 under the mortality bases considered.

Table 3: Assumptions adopted for the projection of superannuation balances

\begin{tabular}{|c|c|}
\hline Item & Assumption \\
\hline Salary & $\begin{array}{l}\text { In accordance with salary distribution estimated from } \\
\text { the ABS Statistics. }\end{array}$ \\
\hline $\begin{array}{l}\text { Starting superannuation } \\
\text { balance }\end{array}$ & $\begin{array}{l}\text { In accordance with the distribution of superannuation } \\
\text { balances estimated from ABS Surveys. }\end{array}$ \\
\hline $\begin{array}{l}\text { General salary increases } \\
\text { due to inflation and } \\
\text { productivity }\end{array}$ & $4.00 \%$ per annum \\
\hline $\begin{array}{l}\text { Promotional salary } \\
\text { increases }\end{array}$ & $\begin{array}{l}\text { In accordance with the distribution of promotional } \\
\text { salary increases for the lower, median and upper } \\
\text { income quartiles estimated from ABS Surveys. }\end{array}$ \\
\hline SGC & $9.00 \%$ per annum ${ }^{31}$ \\
\hline Tax & $15.00 \%$ on both contributions and investment earnings \\
\hline Investment earnings & 6.35\% per annum (nominal) \\
\hline CPI increases & $2.50 \%$ per annum \\
\hline
\end{tabular}

Table 4: Estimated present value of age pension payments (\$2009), for a male aged 67 in 2046

\begin{tabular}{l|l|l|l}
\multicolumn{2}{l}{ PV(age pension) } & \multicolumn{2}{|l}{ Mortality improvements to 2046 } \\
\cline { 3 - 4 } $\begin{array}{l}\text { Mortality } \\
\text { improvements beyond } \\
2046\end{array}$ & 100-year trend & $\$ 236,175$ & $\$ 272,672$ \\
\cline { 2 - 4 } & 25-year trend & $\$ 247,558$ & $\$ 283,163$ \\
\cline { 2 - 4 } & &
\end{tabular}

\section{Annuity Pricing}

In line with calculating EPVs for the age pension, a real (and risk-free) discount rate of 3\% was assumed $^{32}$, and projected mortality assumed mortality improvements continue up to and beyond 2046 according to the stated trend (25- or 100-year trend).

Assumptions regarding annuitant mortality and expenses were based on information obtained from two life insurance consultants. Under voluntary purchase (policy option (a)), annuitant mortality was assumed to be $30 \%$ lower than population mortality at age 60 and $20 \%$ lower than population mortality from age 90 onwards, with linear interpolation between these ages. Under compulsory purchase (policy options (b)-(d)), annuitant mortality was assumed to be population mortality.

Initial expenses were assumed to be $\$ 800$ per policy, with renewal expenses of $\$ 300$ per policy per annum. These expense assumptions are extremely sensitive to volumes sold, and

\footnotetext{
${ }^{30}$ Estimates using 25-year mortality improvement factors represent lighter mortality compared to the 100-year factors, and thus give higher figures in terms of EPV.

${ }^{31}$ Given that an SGC of 9\% is likely to be redundant from 2013 when the first increases to an SGC of $12 \%$ may occur, at the time of writing these increases are "recommendations" rather then enshrined in legislation, and a year is a long time in politics. Later sensitivity analysis considers the relative impact of an SGC of $12 \%$.

32 This assumption implies that future increases in the Pensioner and Beneficiary Living Cost Index (PBLCI) are not larger than increases in CPI, so that age pension payments increase at the assumed rate of inflation of $2.5 \%$ per annum.
} 
are only estimates that would likely change after the introduction of a compulsory annuitisation policy.

Under private provision (policy options (a) and (b)), a profit margin at $15 \%$ of premium and commission charges at $3 \%$ of premium were assumed. Both of these reduced to zero under government provision (policy options (c) and (d)).

\section{RESULTS}

The overall analysis consists of 3 scenarios, to capture uncertainty in future mortality, the influence of an increase in the SGC rate, and future investment earnings on superannuation balances:

1. An SGC rate of $9 \%$ and future mortality dependent on 100 -year improvement factors;

2. An SGC rate of $9 \%$ and future mortality dependent on 25 -year improvement factors;

3. An SGC rate of $12 \%$ and future mortality dependent on 100 -year improvement factors

Each scenario above considers three possible investment returns - the assumed best estimate of $6.35 \%$, and then returns spread $20 \%$ about that estimate (i.e. $6.35 \pm 20 \%$ ).

\section{Scenario 1: SGC = 9\%, and 100-year mortality improvement factors.}

Figure 1 shows how income (annuity plus pension payments) compares under each policy option.

\section{Figure 1: Comparison of total per annum incomes}

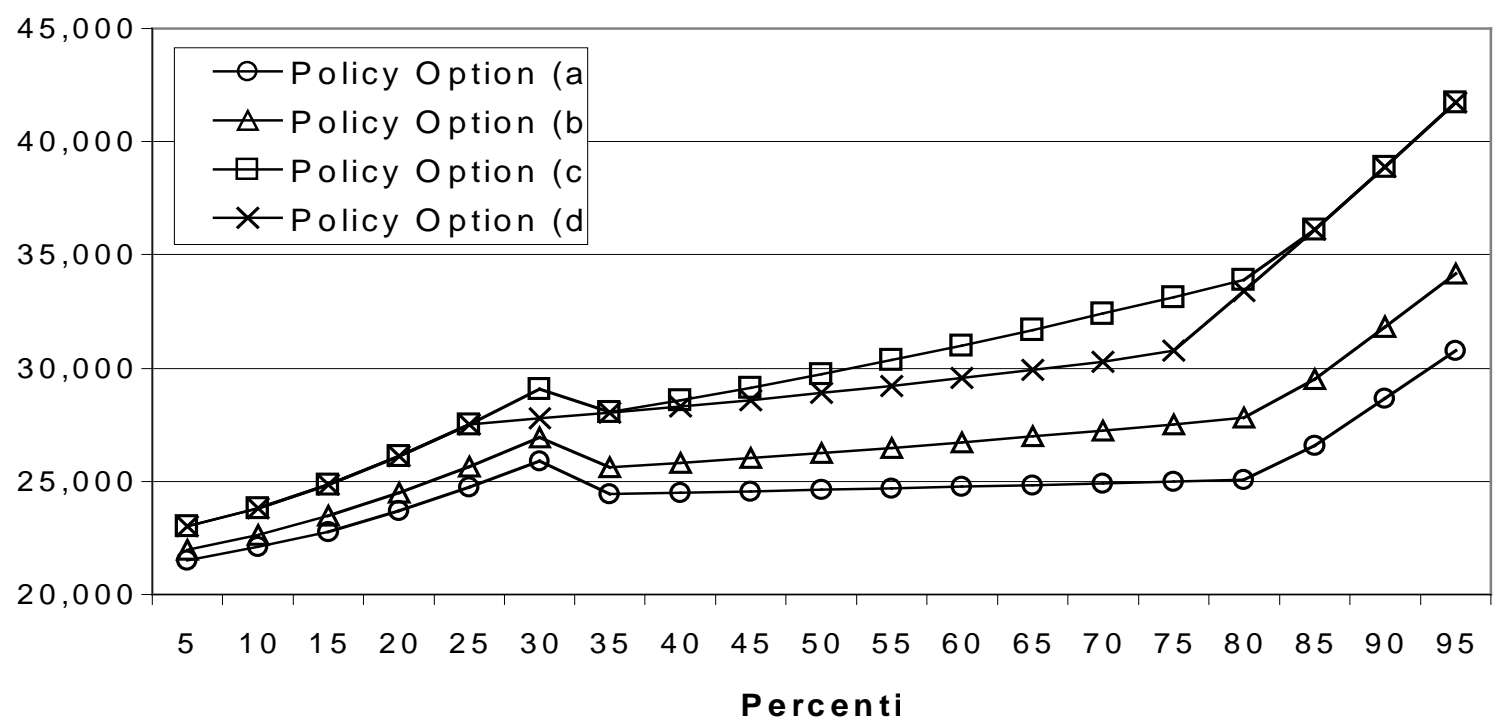

For policy options (a) - (c) there is a noticeable 'hump' in the results at the $30^{\text {th }}$ percentile. This is attributed to the interaction homeownership with the current means test for the age pension, where individuals in the $30^{\text {th }}$ percentile are assumed to be non-homeowners. This 'hump' is smoothed out under policy option (d) when the means test is revised to an income test only. Table 5 summarises various statistics for all policy options. 
Table 5: Comparison between voluntary and compulsory annuitisation

\begin{tabular}{lllll}
\hline $\begin{array}{l}\text { Policy } \\
\text { Option }\end{array}$ & $\begin{array}{l}\text { Average } \\
\text { Income }\end{array}$ & $\begin{array}{l}\text { Median } \\
\text { Income }\end{array}$ & $\begin{array}{l}\% \text { above } \\
\text { ASFA } \\
\text { 'comfortable' } \\
\text { retirement standard }\end{array}$ & $\begin{array}{l}\text { Westpac- } \\
\text { mange of } \\
\text { minimum/ }\end{array}$ \\
\hline (a) & $\$ 24,963$ & $\$ 24,633$ & $0 \%^{2}$ & - \\
\hline (b) & $\$ 26,696$ & $\$ 26,251$ & $0 \%^{2}$ & $(+2.1 \%,+11.1 \%)$ \\
\hline (c) & $\$ 30,481$ & $\$ 29,740$ & $10 \%$ & $(+6.9 \%,+35.7 \%)$ \\
\hline (d) & $\$ 29,836$ & $\$ 28,910$ & $10 \%$ & $(+6.9 \%,+35.7 \%)$ \\
\hline
\end{tabular}

${ }^{1}$ When considering the change in per annum income compared to policy option (a)

${ }^{2}$ Note that this proportion is based on the per annum income for the $95^{\text {th }}$ percentile. While individuals in the top $5^{\text {th }}$ percentile may have incomes above the Westpac-ASFA standard, there is no reliable way to estimate the number of individuals who may fall in this category and as such the proportion is recorded as zero, though clearly it is capped above at $5 \%$.

Clearly, average incomes increase due to (1) compulsion and (2) government provision. Policy option (b) suggests that the benefit of compulsion is that the combined income received via the age pension and an annuity increases for all individuals, with the range of increase between $2.1 \%$ and $11.1 \%$. For policy option (d) which also includes the effects of government provision and amended age pension eligibility rules, a guaranteed minimum per annum income between \$23,007 and \$41,741 (in 2009 dollars) is possible for all individuals between the $5^{\text {th }}$ and $95^{\text {th }}$ percentiles of earners. These are considered to be minimum levels since retirees may derive additional income from employment (not assessed under the modified income test) or other investments. The increase in per annum income varies between $6.9 \%$ and 35.7\%, with a larger effect experienced by those with higher superannuation balances at retirement. All individuals can expect to receive at least $\$ 1,488$ more in retirement income per annum under policy option (d). The proportion of individuals meeting the Westpac-ASFA Standard for a comfortable retirement increases to $10 \%$. Compared to the current situation (policy (a)), all individuals are better off.

Figure 2 shows how receipt of the age pension compares under each policy option.

\section{Figure 2: Comparison of per annum age pension payments}

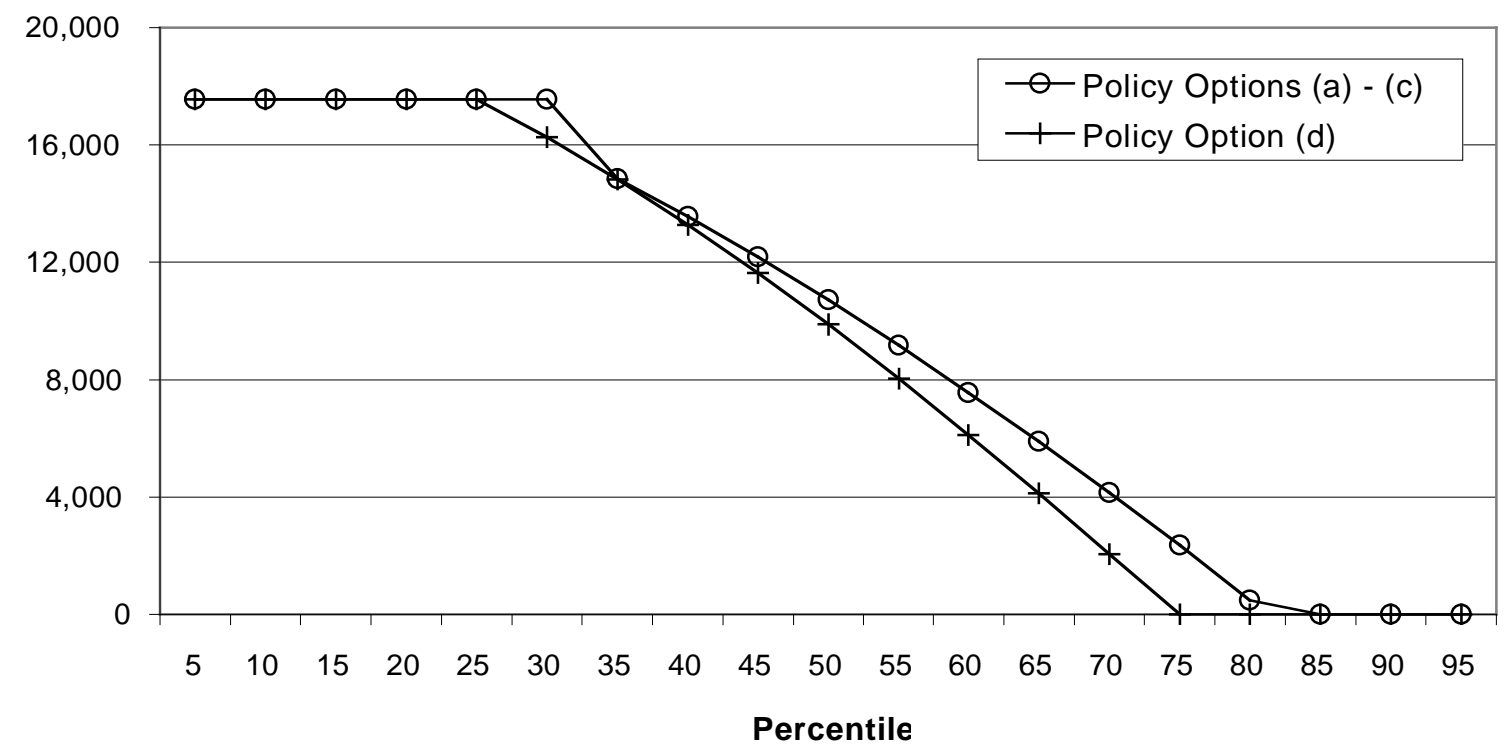


Pension payments under policy options (a) - (c) are not impacted, but under policy option (d) they are lowered due to the strengthening of the income test. Overall, $10 \%$ fewer individuals are expected to receive some form of the age pension and there is a decrease in the amount of payment received by the majority of individuals. This implies an average saving in the cost of the age pension of $6.6 \%$ per person under policy option (d), as the average pension cost for an individual decreases from $\$ 131,854$ under policy options (a) (c), to $\$ 123,175$ under policy option (d).

As a result, individuals between the $25^{\text {th }}$ and $85^{\text {th }}$ percentiles experience a decrease in overall income when moving from policy option (c) to policy option (d) due to a decrease in the amount of the age pension payment received. This result however, is deemed to be acceptable as the revised means test better targets the age pension at those who need it most.

In terms of sensitivity to changes in the investment earnings on superannuation funds, as expected, the level of retirement income changes in line with the movement of investment earnings. Table 6 summarises the results.

Under a 9\% SGC, a compulsory annuitisation policy is potentially welfare-improving when future mortality experience follows the 100-year trend; not only are individuals expected to receive higher income in retirement, but the average cost of the age pension is expected to fall by up to10.5\% per person (depending on the investment earnings experience).

Table 6: Changes in average per annum income between policy option (a) base case and policy options (b) - (d), under 9\% SGC and 100-year mortality trends

\begin{tabular}{|lllll}
\hline \multirow{2}{*}{$\begin{array}{l}\text { Policy } \\
\text { option }\end{array}$} & & \multicolumn{2}{l}{ Investment Earnings } \\
\cline { 3 - 5 } & & $20 \%$ Lower & Base Case $^{33}$ & $20 \%$ Higher \\
\hline \multirow{2}{*}{ (a) } & Increase in income & - & - & - \\
\hline \multirow{2}{*}{ Saving in pension cost } & - & - & - \\
\hline & Increase in income & $+5.8 \%$ & $+6.9 \%$ & $+7.9 \%$ \\
\hline \multirow{2}{*}{ (c) } & Saving in pension cost & $0.0 \%$ & $0.0 \%$ & $0.0 \%$ \\
\hline & Increase in income & $+18.3 \%$ & $+22.1 \%$ & $+25.5 \%$ \\
(d) & Saving in pension cost & $0.0 \%$ & $0.0 \%$ & $0.0 \%$ \\
\hline & Increase in income & $+15.7 \%$ & $+19.5 \%$ & $+22.5 \%$ \\
\hline
\end{tabular}

Scenario 2: SGC = 9\%, and 25-year mortality improvement factors.

Under the lighter mortality assumption (25-year mortality trends), the differences in income and pension savings over the four policy options are given below.

\footnotetext{
${ }^{33}$ The figures in this column can be derived from table 5: with policy (a) average income equal to 24,963 , the policy (b) figure of 26,696 represents a $6.9 \%$ increase, 30,481 is a $22.1 \%$ increase, and 29,836 is a $19.5 \%$ increase.
} 
Table 7: Changes in average per annum income and pension costs, under 9\% SGC and 25year mortality trends

\begin{tabular}{|c|c|c|c|c|}
\hline \multirow{2}{*}{$\begin{array}{l}\text { Policy } \\
\text { option }\end{array}$} & & \multicolumn{3}{|c|}{ Investment Earnings } \\
\hline & & 20\% Lower & Base Case & 20\% Higher \\
\hline (a) & $\begin{array}{l}\text { Increase in income } \\
\text { Saving in pension cost }\end{array}$ & - & - & \\
\hline (b) & $\begin{array}{l}\text { Increase in income } \\
\text { Saving in pension cost }\end{array}$ & $\begin{array}{l}+3.0 \% \\
+0.0 \% \\
\end{array}$ & $\begin{array}{l}+3.6 \% \\
0.0 \%\end{array}$ & $\begin{array}{l}+4.1 \% \\
+0.0 \% \\
\end{array}$ \\
\hline (c) & $\begin{array}{l}\text { Increase in income } \\
\text { Saving in pension cost }\end{array}$ & $\begin{array}{l}+14.1 \% \\
0.0 \%\end{array}$ & $\begin{array}{l}+17.3 \% \\
0.0 \%\end{array}$ & $\begin{array}{l}+20.2 \% \\
0.0 \%\end{array}$ \\
\hline (d) & $\begin{array}{l}\text { Increase in income } \\
\text { Saving in pension cost }\end{array}$ & $\begin{array}{l}+19.6 \% \\
-10.3 \%\end{array}$ & $\begin{array}{l}+21.7 \% \\
-10.5 \%\end{array}$ & $\begin{array}{l}+22.6 \% \\
-7.5 \%\end{array}$ \\
\hline
\end{tabular}

Again, increases in individual income are evident but for policy options (b) and (c), this is to a lower degree than under 100-year mortality improvements. This is expected as the lighter mortality gives a smaller annuity payment at retirement.

However, the results under policy option (d) strongly highlight the need for the pension eligibility rules to take account of changes in future mortality. Higher individual incomes are derived, but this is now at a cost of higher pension payments than the current situation. It is clear that a change in the assumed mortality rates requires additional revision of age pension means-testing to ensure that retirees are not benefitting from a compulsory annuitisation policy at the expense of tax-payers.

Scenario 3: SGC = 12\%, and 100-year mortality improvement factors.

Naturally the additional contributions under 12\% SGC lead to a higher average income overall, under the base mortality and investment assumptions.

Table 8: 9\% SGC versus 12\% SGC

\begin{tabular}{llll|l}
\hline $\begin{array}{l}\text { Policy } \\
\text { Option }\end{array}$ & $\begin{array}{l}\text { Average } \\
\text { Income under } \\
9 \%\end{array}$ & $\begin{array}{l}\text { Average } \\
\text { Income under } \\
12 \%\end{array}$ & $\begin{array}{l}\text { Pension saving } \\
\text { under } 9 \%^{1}\end{array}$ & $\begin{array}{l}\text { Pension saving } \\
\text { under } 12 \%^{1}\end{array}$ \\
\hline (a) & $\$ 24,963$ & $\$ 27,323$ & - & - \\
\hline (b) & $\$ 26,696$ & $\$ 29,482$ & $+0.0 \%$ & $+0.0 \%$ \\
\hline (c) & $\$ 30,481$ & $\$ 34,257$ & $+0.0 \%$ & $+0.0 \%$ \\
\hline (d) & $\$ 29,836$ & $\$ 33,354$ & $+6.6 \%$ & $+11.2 \%$ \\
\hline
\end{tabular}

${ }^{1}$ When considering the change in per annum income compared to policy option (a) for that level of SGC.

Sensitivity to investment earnings are given below. 
Table 9: Changes in average per annum income and pension cost, under 12\% SGC and 100-year mortality trends

\begin{tabular}{|lllll}
\hline Policy & & \multicolumn{2}{l}{ Investment Earnings } \\
\cline { 3 - 5 } & & $20 \%$ Lower & Base Case & $20 \%$ Higher \\
\hline & & & & \\
\hline & Increase in income & - & - & - \\
\hline \multirow{2}{*}{ (a) } & Saving in pension cost & - & - & - \\
\hline (b) & Increase in income & $+7.0 \%$ & $+7.9 \%$ & $+8.7 \%$ \\
& Saving in pension cost & $+0.0 \%$ & $+0.0 \%$ & $+0.0 \%$ \\
(c) & Increase in income & $+22.2 \%$ & $+25.4 \%$ & $+28.0 \%$ \\
\hline \multirow{2}{*}{ (d) } & Saving in pension cost & $+0.0 \%$ & $+0.0 \%$ & $+0.2 \%$ \\
\hline & Increase in income & $+19.4 \%$ & $+22.1 \%$ & $+23.7 \%$ \\
\hline
\end{tabular}

As expected, not only do higher overall incomes eventuate but there are also higher relative benefits of compulsion with $12 \%$ SGC. The average income increases due to compulsion by $7.9 \%$, compared to $6.9 \%$ with $9 \%$ SGC. There is also a greater average saving in the cost of the age pension compared to that under 9\% SGC. This 'welfare improving' situation is of much interest given the obvious public policy goals - to improve individual situations, at a lower public cost than otherwise.

The results for $12 \%$ SGC demonstrate less sensitivity to changes in the assumption settings compared to an SCG of 9\%, for policy option (d). This is indicated by the smaller range of the average increase in per annum income under 12\% SGC (19.4\%, 23.7\%) compared to that under 9\% SGC (15.7\%, 22.5\%).

However, with a $12 \%$ SGC rate the sensitivity analysis indicates that while incomes increase for the majority of retirees, adjusting the investment earnings assumption results in some individuals between the $20^{\text {th }}$ and $30^{\text {th }}$ percentiles receiving lower per annum incomes. This is due to the interaction of assumptions regarding homeownership with age pension means-testing, whereby the removal of the assets test and strengthening of the income test leads to a faster decrease in the rate of eligible pension payment for individuals in the $30^{\text {th }}$ percentile. The implication is that additional revision of means-testing and other economic policies that affect retirement incomes is required when the assumption settings change.

The overall analysis shows that the effect of compulsory annuitisation on income is larger for those at either end of the range for superannuation balances at retirement. The highest per annum incomes are naturally achieved under 100-year trend mortality improvements, $12 \%$ SGC and an assumption of higher investment earnings, but within this scenario there are individuals who would potentially be worse off. Additionally there is only a minor saving in the cost of the age pension (0.2\%).

\section{CONCLUSION}

In conjunction with the Government provided age pension, compulsory annuitisation provides a policy option by which to guarantee all individuals a certain level of income in retirement. The analysis quantifies, for a single male under certain assumptions ${ }^{34}$, a range of

\footnotetext{
${ }^{34}$ The authors acknowledge that there are a number of limitations with any set of adopted assumptions. For example, some rely on general relationships between the variables such as individuals in the bottom $30^{\text {th }}$ percentile of superannuation balances being non-homeowners. Many parameter values adopted are estimates based on past experience, which may not necessarily be representative of the future; characteristics such as the
} 
increases in income and changes in the cost of the age pension. The higher annual incomes apparent in moving through the policy options arises due to firstly, a reduced price for annuities due to a more effective pooling of longevity risk, and secondly the underlying assumptions around government versus private provision. The more effective pooling arises because mortality experience will more closely reflect that of the general population as opposed to a 'select' population under voluntary annuitisation.

Scenario 1 shows that compulsory annuitisation is potentially welfare improving, with a decrease in the average cost of the age pension and all individuals expected to receive higher incomes in retirement. However other scenarios demonstrate that potential benefits are dependent on future experience regarding mortality improvements, investment earnings and the level of superannuation contributions. Results were shown to be more sensitive to a change in mortality experience than to changes in the other parameters: in particular, an improvement in mortality experience converts the change in the average cost of the age pension from a saving to a loss. This reinforces that ongoing revision of age pension meanstesting is required in order to strike a balance between improving income levels in retirement and increasing the financial burden for tax-payers.

The suggestion of compulsion may or may not be a politically acceptable approach, but nonetheless sets out one way to view Australia's retirement income system which, in light of current future expectations, is becoming an increasingly important issue. Given the trends toward an ageing population, an increasing cost of funding the age pension and in light of the significant risks an individual faces in retirement, a compulsory annuitisation policy could potentially benefit Australia in its entirety by ensuring individuals use their superannuation balances for their intended purpose: to fund their retirement.

\section{FUTURE RESEARCH}

Future research could consider other factors that impact income in retirement, such as voluntary superannuation contributions, rent assistance payments, income from other sources, and the utility of other products. Analysis in response to obvious objections to compulsion such as the treatment of those in poor health are not developed at this stage. Additionally, changes in expenditure levels during retirement are not accounted for in terms of adequacy but rather, the stated industry norms are adopted. The research could be extended to analyse the expected effects for other cohorts such as females, couples and part-time employees. This would be required to estimate the overall impact compulsory annuitisation could have for all retirees.

Alternative policy variations of compulsory annuitisation could be investigated, as the results are clearly dependent on the particular policy adopted. Having options of guaranteed or value-protected annuities; and considering the role that the Government could play under private provision of annuities are two such areas of interest ${ }^{35}$.

\footnotetext{
working status of individuals do not change over the projection period; and future mortality is highly uncertain. The overall sensitivity analysis adopted attempts to display some of the uncertainty involved in the major assumptions.

${ }^{35}$ This is especially so given that the large increases in income under policy options (c) and (d) are due not just to directly attributable advantages of compulsion, but the elimination of profit and commission criteria under government provision. As such an analysis of the potential impacts of compulsory annuitisation on expenses in annuity pricing would also provide a more detailed understanding of the financial implications of such a policy.
} 


\section{REFERENCES}

ABS (Australian Bureau of Statistics) 1988, Year Book Australia 1988, Australian Bureau of Statistics, Canberra.

: 2007a, Survey of Income and Housing -Confidential Unit Record Files, 2005-06, Australian Bureau of Statistics, Canberra.

: 2007b, Household Wealth and Wealth Distribution, 2005-06, Australian Bureau of Statistics, Canberra.

: 2008a, Year Book Australia 2008, Australian Bureau of Statistics, Canberra.

: 2008b, Survey of Employment Arrangements, Retirement and Superannuation (SEARS 2007), Australian Bureau of Statistics, Canberra.

: 2008c, Life Tables, Australia, 2005-07, Australian Bureau of Statistics, Canberra.

: 2009a, Average Weekly Earnings, Australia, Australian Bureau of Statistics, Canberra.

: 2009b, Regional Wage and Salary Earner Statistics, Australia - Data Cubes, 2005-06, Australian Bureau of Statistics, Canberra.

: 2009c, Household Income and Income Distribution, 2007-08, Australian Bureau of Statistics, Canberra.

AFR (Australian Financial Review) 2009, 'Annuities come back from the dead', Australian Financial Review, 25 November 2009, p.27.

AGA (Australian Government Actuary) 2004, Australian Life Tables 2000-02, Australian Government Actuary, Canberra.

ANZ (Australian and New Zealand Banking Group) 2002, ANZ Survey of Adult Financial Literacy in Australia - Final Report, Roy Morgan Research.

: 2005, ANZ Survey of Adult Financial Literacy in Australia, AC Nielson Research.

: 2008, ANZ Survey of Adult Financial Literacy in Australia, The Social Research Centre.

APRA (Australian Prudential Regulation Authority) 2007, 'A recent history of superannuation in Australia', APRA Insight, Issue No.2 (Special Edition), Australian Prudential Regulation Authority, Sydney.

Atkinson, M, Creedy, J \& Knox, D 1999, 'Alternative Retirement Income Arrangements and Lifetime Income Inequality: Lessons from Australia', International Tax and Public Finance Vol. 6, pp. 103-117. http://dx.doi.org/10.1023/A:1008604121778

Banks, J, Emmerson, C \& Oldfield, Z 2004, 'Not so brief lives: longevity expectations and wellbeing in retirement', in I. Stewart and R. Vaitilingam (eds.), Seven Ages of Man and Woman, Swindon: Economic and Social Research Council, pp. 28-31.

Bernheim, D 1991, 'How Strong are Bequest Motives? Evidence based on Estimates of the Demand for Life Insurance and Annuities', Journal of Political Economy, Vol. 99, No.

5. http://dx.doi.org/10.1086/261783

Brown, JR, Casey, M \& Mitchell, OS 2008, 'Who Values the Social Security Annuity?

Evidence from the Health and Retirement Study', NBER Working Paper No. W13800.

Cannon, E \& Tonks, I 2008, Annuity Markets, Oxford University Press, New York. http://dx.doi.org/10.1093/acprof:oso/9780199216994.001.0001

Centrelink 2009, 'Income and asset tests for Age Pension', Age Pension: Payment and claiming, accessed: 6/9/2009,

$<$ http://www.centrelink.gov.au/internet/internet.nsf/payments/age_iat. htm>.

Clare, R 2007, 'Are Retirement Savings On Track?', The Association of Superannuation Funds of Australia (ASFA) Research and Resource Centre, June 2007.

Commonwealth of Australia 2009, 'Secure and Sustainable Pensions', 2009-10 Commonwealth Budget - Pensions Overview, May 2009. 
: 2010, Fact Sheet: Superannuation - Increasing The Superannuation Rate To 12 Per

Cent, accessed: 22/11/2010,

http://www.futuretax.gov.au/documents/attachments/Fact_Sheet_SG\%20_rate_increase .pdf.

DWP (Department for Work and Pensions) 2002, Simplicity, Security and Choice: Working and Saving in Retirement, The Stationery Office, Command Paper 5677.

FaHCSIA (Department of Families, Housing, Community Services and Indigenous Affairs) 2008, Pension Review: Background Paper, paper released by Dr Jeff Harmer of FaHCSIA to support the public consultation and submission process of the Harmer Pension Review.

: 2009, Guide to Social Security Law, Commonwealth of Australia.

FLF (Financial Literacy Foundation) 2007, Financial Literacy: Australians Understanding Money, Australian Government Financial Literacy Foundation, Commonwealth of Australia.

Fong, W 2002, 'On the Cost of Adverse Selection in Individual Annuity Markets: Evidence from Singapore', Journal of Risk and Insurance, Vol. 69, No. 2.

http://dx.doi.org/10.1111/1539-6975.00014

HM Treasury 2006, The Annuities Market, The Stationery Office, London.

Hurd, M 1987, 'Savings of the Elderly and Desired Bequests', American Economic Review, Vol. 77, No. 3.

: 1989, 'Mortality Risk and Bequests', Econometrica, Vol. 54, No. 4.

IAAust (Institute of Actuaries of Australia) 2002, Superannuation and Standards of Living in Retirement, Submission to the Senate Select Committee on Superannuation \& Financial Services, Institute of Actuaries of Australia, Sydney.

: 2009, The Practice of Life Insurance, The Institute of Actuaries of Australia, Sydney, 2009 Ed.

IFSA (Investment and Financial Services Association) 2007, IFSA Retirement Income Streams Report, Investment and Financial Services Association.

Laitner, J \& Juster, F 1996, 'New Evidence on Altruism: A Study of TIAA-CREF Retirees', American Economic Review, Vol. 86, No. 4.

Lewis, S 2009, 'The UK Annuities Market: Structure, Trends \& Innovation', International Conference on Annuities Markets, Tokyo.

Loh, M \& Gosden, M 2007, 'Variable Annuities', The Actuary, June 2007.

MacDonald, BJ, Jones, B, Morrison, RJ, Brown, RL \& Hardy, M 2011, 'Research and Reality - A Literature Review on Drawing Down Retirement Savings'. Society of Actuaries. http://www.soa.org/research/research-projects/pension/default.aspx.

McDonald, $\mathrm{P}$ \& Kippen, $\mathrm{R}$ 2004, Ageing: the social and demographic dimensions, http://hdl.handle.net/1885/41450.

Mercer 2009, 'PSS and CSS Long Term Cost Report 2008', report prepared for the Department of Finance and Deregulation, Commonwealth of Australia, Canberra.

NATSEM (National Centre for Social and Economic Modelling) 2009, 'Reform of the Australian Retirement Income System, NATSEM Research Report.

O’Brien, C, Fenn, P \& Diacon, S 2005, How long do people expect to live? Results and Implications, Centre for Risk and Insurance Studies Research report 2005-1, Nottingham University Business School, UK.

OECD (Organisation for Economic Co-operation and Development) 2009, Pensions at a Glance 2009: Retirement-Income Systems in OECD Countries (www.oecd.org/els/social/pensions/PAG).

Officer, B \& Bishop, S 2008, 'Term of Risk Free Rate’, Prepared for Energy Networks Association, Value Advisor Associates, Melbourne. 
Rawlinson, D \& Cater, M 2008, 'Retirees’ Longevity Risk', $4^{\text {th }}$ Financial Services Forum, Melbourne, Institute of Actuaries of Australia.

RBA (Reserve Bank of Australia) 2009a, 'Table G.06 Labour Costs', accessed 15/8/2009, $<$ www.rba.gov.au >.

: 2009b, 'The Monetary Policy Framework', accessed 15/8/2009, <www.rba.gov.au/MonetaryPolicy/about_monetary_policy.html>.

Rowlingson, K \& McKay, S 2005, Attitudes to Inheritance in Britain, Joseph Rowntree Foundation (The Policy Press).

Sherris, M \& Evans, J 2009, 'Longevity Management Issues for Australia’s Tax System', accessed 9/12/2009,

http://taxreview.treasury.gov.au/Content/html/commissioned_work/downloads/Longevi ty_Management_Issues.pdf.

Super Ratings 2009, 'Complete Final Super Returns on Australia's Largest Funds', SuperRatings Media, released 27/7/2009.

Treasury 2007, Intergenerational Report 2007, Commonwealth of Australia. : 2010, Intergenerational Report 2010, Commonwealth of Australia.

Westpac-ASFA 2009, 'Detailed budget breakdowns for comfortable and modest lifestyles, National, March Quarter 2009’, accessed 13/5/2009, <www.superannuation.asn.au>.

Wilhelm, M 1996, 'Bequest Behavior and the Effect of Heirs' Earnings: Testing the Altruistic Model of Bequests', American Economic Review, Vol. 86, No. 4.

Yaari, M 1965, 'Uncertain Lifetime, Life Assurance and the Theory of the Consumer', Review of Economic Studies, Vol. 32, No. 2. http://dx.doi.org/10.2307/2296058 


\section{APPENDIX A: ASSUMPTIONS FOR PROJECTION OF SUPERANNUATION BALANCES}

Table 10 summarises the adopted distribution of salaries and superannuation balances for 30 year-old males, as at 2009 as this is the starting year for projections. All values are in 2009 dollars.

Table 10: Distribution of Salaries and Superannuation Balances for males aged 30, 2009

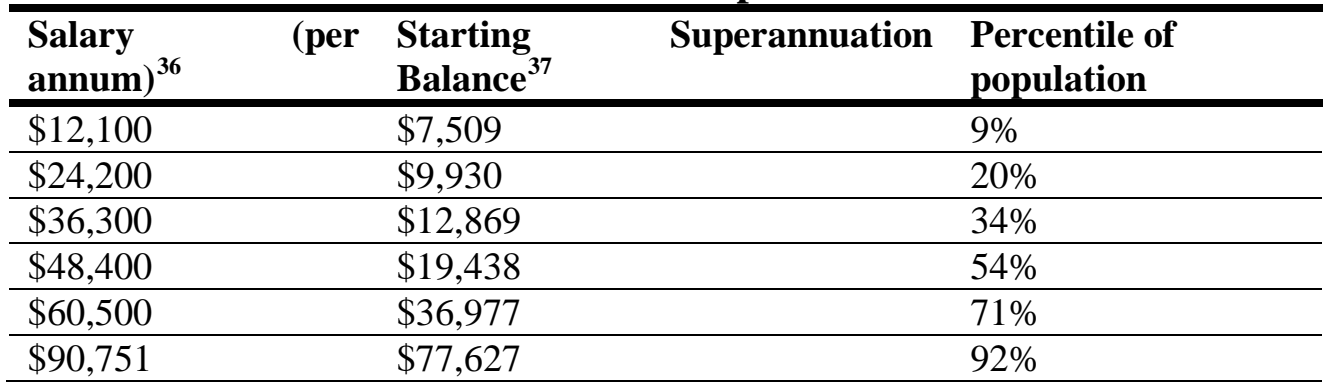

Source: ABS (2008b, 2009a)

Salaries increase over time due to inflation, productivity and promotion. For increases due to inflation and productivity, $4 \%$ per annum was assumed ${ }^{38}$. For increases due to promotion, estimates from the Survey of Income and Housing Costs Confidential Unit Record Files (ABS, 2007a) ${ }^{39}$ were used. Table 11 shows the assumed promotional increases implied from the earnings profiles:

Table 11: Promotional Salary Increase Assumptions, males

\begin{tabular}{llll}
\hline & \multicolumn{3}{l}{$\begin{array}{l}\text { Promotional Salary Increases } \\
\text { (\% per annum at age and income quartile shown) }\end{array}$} \\
\cline { 2 - 4 } Age Attained & Lower Quartile & Median & Upper Quartile \\
\hline 27 & 2.1 & 2.6 & 3.6 \\
\hline 32 & 0.0 & 1.0 & 1.4 \\
\hline 37 & 0.0 & 0.0 & 1.0 \\
\hline $42+$ & 0.0 & 0.0 & 0.0 \\
\hline
\end{tabular}

\footnotetext{
${ }^{36}$ Data on the salary distribution for the 25 - 34 age cohort of males was extracted from the ABS 2005-06 Regional Wage and Salary Earner Statistics. Values were inflated to reflect 2009 prices using Average Weekly Ordinary Time Earnings (AWOTE) for full-time males (ABS, 2009b).

${ }^{37}$ Given that superannuation contributions are calculated as a proportion of an individual's employment income, a proportional relationship between salary and superannuation balance as at 2009 was assumed. Data on the distribution of superannuation balances for the 25 - 34 age cohort of males was extracted from the 2007 Survey of Employment Arrangements, Retirement and Superannuation (ABS, 2008b). Balances corresponding to the salary percentiles were interpolated from this distribution, and were inflated to reflect 2009 prices by applying the change in AWOTE (ABS, 2009b).

${ }^{38}$ This is the increase in Average Weekly Earnings (AWE) from March 2004 to March 2009 (RBA, 2009a) and is consistent with the Commonwealth's long-term view on general salary increases (Mercer, 2009).

39 The extracted earnings profiles of males are cross-sectional, implying that any differences in income across age groups can be attributed to promotional increases or differences in the population distribution for the age groups. The profiles suggest that the rate of promotional increases are greater for higher incomes and also persist for longer. The promotional salary increases for the lower income quartile are relatively small, and the aggregate effects of promotional salary increases are also small relative to the assumed $4 \%$ for general salary increases.
} 


\section{Economic Assumptions}

The nominal investment earnings rate, net of management fees, was assumed to be $6.35 \%$ per annum, which equals the 10-year rolling return to June 2009 on a balanced investment option $^{40}$. Tax on contributions and investment earnings was assumed to remain at the current rate of $15 \%$.

General inflation was assumed at 2.5\% per annum, consistent with the Reserve Bank of Australia target of CPI (Consumer Price Index) being in the range of $2 \%-3 \%$, as well as well as the long-term inflation forecasts of the 2007 Intergenerational Report and the RBA's August 2009 Statement on Monetary Policy (Treasury, 2007; RBA, 2009b).

\footnotetext{
${ }^{40}$ This assumption was considered to be appropriate, given that over $80 \%$ of major super fund members invest in the default option, which is commonly a balanced investment option (Super Ratings, 2009), and is consistent with the Commonwealth's view on long-term nominal investment returns (Mercer, 2009).
} 


\section{APPENDIX B: FITTED REGRESSION FOR SUPERANNUATION PROJECTIONS}

A polynomial regression was fit to the point estimates of superannuation balances. A regression without an intercept, as well as parabolas and straight lines (each with and without intercepts) were found to be inferior fits according to the p-values, R square and Adjusted Rsquare measures ${ }^{41}$. The regression statistics of the resulting distribution are shown in Table 12.

Table 12: Regression statistics

\begin{tabular}{llllll}
\hline & Coefficients & Standard Error & P-value & R Square & $\begin{array}{l}\text { Adjusted } \\
\text { R Square }\end{array}$ \\
\cline { 1 - 4 } Intercept & 97738 & 24925 & 0.0172 & & \\
\cline { 1 - 4 } (Percentile) $^{1.5}$ & 723721 & 52691 & 0.0002 & 0.9792 & 0.9740 \\
\hline
\end{tabular}

The distribution of superannuation balances between the $5^{\text {th }}$ and $95^{\text {th }}$ percentiles is shown below:

Fitted regression for distribution of superannuation balances for males aged 67, 2046 (\$2009)

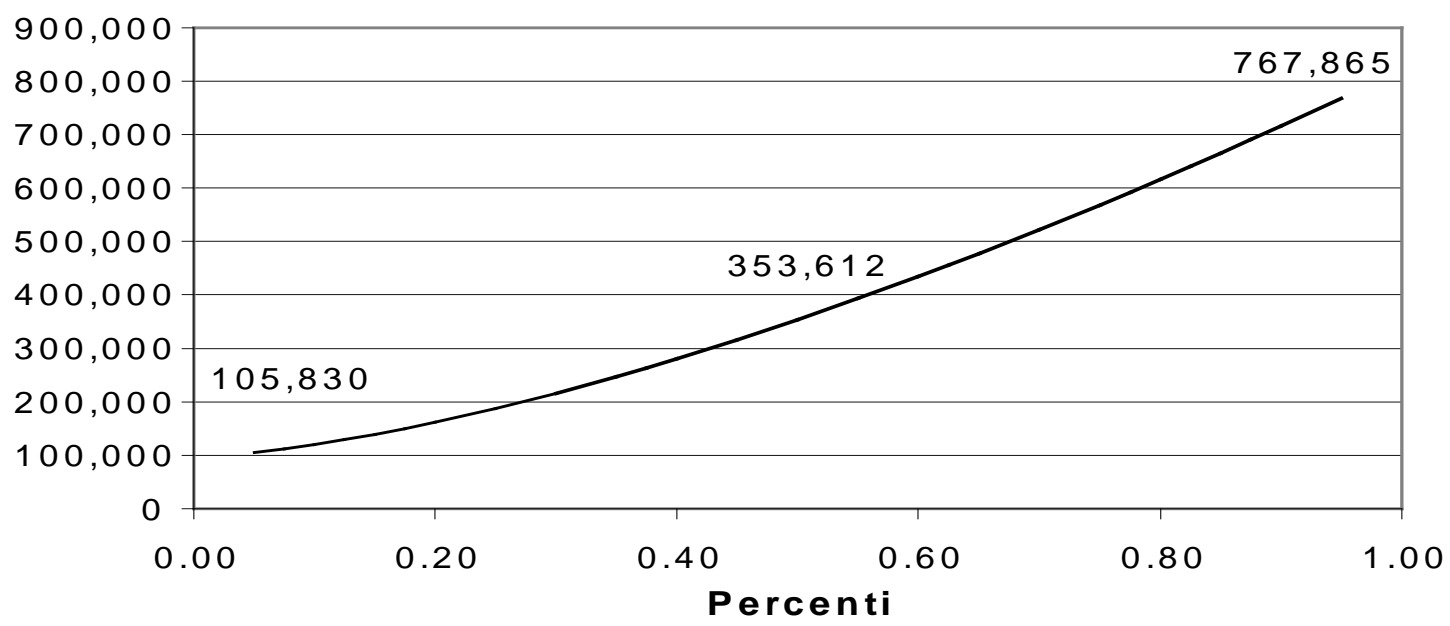

The fitted model is:

Superannuation balance $_{i}=97,738+723,721\left(\text { percentile }_{i}\right)^{1.5}$, for $0.05<i<0.95$

\footnotetext{
${ }^{41}$ While a parabola with an intercept provided a comparable fit to the data according to these measures (an Rsquare and Adjusted R-square measure of 0.9756 and 0.9695 respectively), it was not favoured over the adopted regression primarily due to the degree of over-estimation for balances in the $20^{\text {th }}$ percentile. It is considered that greater weight should be given to the point estimate for the $9^{\text {th }}$ percentile because individuals in lower percentiles are more likely to qualify for the age pension.
} 


\section{APPENDIX C: ASSUMPTIONS FOR AGE PENSION PROJECTIONS}

\section{Homeownership Status And Level Of Assessable Assets At Retirement}

Individuals in the top $70^{\text {th }}$ percentile of superannuation balances were assumed to be homeowners, given that $69 \%$ of single individuals aged over 65 own their own home without a mortgage (ABS, 2009c), and that the probability of being a homeowner increases with overall wealth $^{42}$.

Superannuation balances and the value of owner-occupied dwellings (where applicable) are the two main assets of households (ABS, 2007b). With the family home excluded from the age pension asset test, assessable assets were assumed to be based on superannuation balances at retirement. Policy options (a) to (c) assumed individuals in the $30^{\text {th }}$ percentile had assessable assets equal to $75 \%$ of their superannuation balance (with the balance of the superannuation account after annuitisation assumed to settle outstanding debts), and those in the top $70^{\text {th }}$ percentile were assumed to be debt-free and their assessable assets were assumed as $100 \%$ of their superannuation balance.

\section{Discount Rate}

It is common practice to assume that the nominal risk-free discount rate is the current yield on an Australian Government bond with 10-year maturity (Officer \& Bishop, 2008). A figure of $5.5 \%$ per annum was therefore assumed as this is the average per annum yield between June 2004 and June 2009, and the per annum yield as at June 2009. Given the long-tailed nature of age pension payments, this was assumed as the nominal discount rate, and when adjusted for inflation (CPI) a real risk-free discount rate of $3 \%$ was obtained.

\section{Mortality experience}

The Australian Government Actuary (AGA, 2004) produces official mortality tables for tax and social security purposes, therefore the AGA 2000-02 Mortality Table for males was assumed to represent current mortality rates $\left(q_{x}\right)^{43}$. For projected mortality, mortality improvement factors from the AGA were adopted ${ }^{44}$. These are given below.

\footnotetext{
${ }^{42}$ Given an absence of information regarding the distribution of wealth for single individuals aged 67 and over, the superannuation balance at this age is taken, where required, as an indication of relative wealth throughout the analysis.

${ }^{43}$ In contrast to more recent ABS tables, the AGA tables calculate exposure on actual population, rather than the estimated resident population. The AGA 2000-02 and ABS 2005-07 (ABS, 2008c) mortality rates for males are similar between the ages of 67 and 89, but if the ABS rates were assumed, then mortality rates after age 89 would be heavier than the true mortality rates, as estimated by the AGA.

44 These are the 25-year and 100-year mortality improvement factors, with the 25-year improvement factors representing greater levels of improvement. The improvement factors are calculated as geometric averages over the relevant periods and then smoothed using spline functions.
} 
Table 13: Mortality rates and improvement factors, males from age 67

\begin{tabular}{|c|c|c|c|}
\hline \multirow[b]{2}{*}{ Age } & \multirow[b]{2}{*}{$\mathbf{q}_{\mathrm{x}}$} & \multicolumn{2}{|c|}{ Mortality Improvement Factors } \\
\hline & & 25-year trend (\%) & 100 -year trend (\%) \\
\hline 67 & 0.0173 & -2.9235 & -1.0391 \\
\hline 68 & 0.0191 & -2.8659 & -1.0011 \\
\hline 69 & 0.0211 & -2.8065 & -0.9554 \\
\hline 70 & 0.0234 & -2.7453 & -0.9025 \\
\hline 71 & 0.0259 & -2.6826 & -0.8537 \\
\hline 72 & 0.0287 & -2.6183 & -0.8268 \\
\hline 73 & 0.0318 & -2.5526 & -0.8153 \\
\hline 74 & 0.0353 & -2.4856 & -0.8024 \\
\hline 75 & 0.0392 & -2.4174 & -0.7893 \\
\hline 76 & 0.0435 & -2.3481 & -0.7774 \\
\hline 77 & 0.0482 & -2.2779 & -0.7666 \\
\hline 78 & 0.0534 & -2.2067 & -0.7520 \\
\hline 79 & 0.0588 & -2.1348 & -0.7376 \\
\hline 80 & 0.0640 & -2.0622 & -0.7319 \\
\hline 81 & 0.0697 & -1.9891 & -0.7214 \\
\hline 82 & 0.0769 & -1.9154 & -0.6988 \\
\hline 83 & 0.0855 & -1.8415 & -0.6650 \\
\hline 84 & 0.0951 & -1.7673 & -0.6269 \\
\hline 85 & 0.1056 & -1.6643 & -0.5890 \\
\hline 86 & 0.1165 & -1.5648 & -0.5516 \\
\hline 87 & 0.1276 & -1.5083 & -0.5191 \\
\hline 88 & 0.1386 & -1.4633 & -0.4923 \\
\hline 89 & 0.1493 & -1.4271 & -0.4716 \\
\hline 90 & 0.1593 & -1.3967 & -0.4593 \\
\hline 91 & 0.1683 & -1.3693 & -0.4562 \\
\hline 92 & 0.1764 & -1.3421 & -0.4593 \\
\hline 93 & 0.1844 & -1.3123 & -0.4648 \\
\hline 94 & 0.1931 & -1.2769 & -0.4710 \\
\hline 95 & 0.2021 & -1.2332 & -0.4799 \\
\hline 96 & 0.2107 & -1.1556 & -0.4942 \\
\hline 97 & 0.2193 & -1.0747 & -0.5123 \\
\hline 98 & 0.2278 & -0.9938 & -0.5329 \\
\hline 99 & 0.2363 & -0.9129 & -0.5723 \\
\hline 100 & 0.2448 & -0.8319 & -0.6415 \\
\hline
\end{tabular}

Source: AGA (2004)

Projected mortality rates for males in 2046 incorporating future improvements were calculated according to the following formula:

$\mathrm{q}_{\mathrm{x}}(\mathrm{t})=\mathrm{q}_{\mathrm{x}} \mathrm{x}\left[1+\mathrm{I}_{\mathrm{x}} / 100\right]^{\mathrm{t}-2009}$

where, $\mathrm{q}_{\mathrm{x}}(\mathrm{t})=$ mortality rate at age $\mathrm{x}$ in year $\mathrm{t}$;

$\mathrm{q}_{\mathrm{x}}=$ current mortality rate at age $\mathrm{x}$;

$\mathrm{I}_{\mathrm{x}}=$ rate of mortality improvement at age $\mathrm{x}$.

Table 14 shows the estimated mortality rates for males, should mortality improvements continue up to and beyond 2046, according to the 25- and 100-year mortality improvement factors. 
Table 14: Projected mortality rates for males from 2046

\begin{tabular}{|c|c|c|}
\hline \multirow[b]{2}{*}{ Age } & \multicolumn{2}{|c|}{$\begin{array}{l}\mathrm{q}_{\mathrm{x}} \text { according to mortality } \\
\text { improvement factors }\end{array}$} \\
\hline & 25-year trend & 100-year trend \\
\hline 67 & 0.0058 & 0.0118 \\
\hline 68 & 0.0063 & 0.0130 \\
\hline 69 & 0.0070 & 0.0145 \\
\hline 70 & 0.0077 & 0.0163 \\
\hline 71 & 0.0085 & 0.0182 \\
\hline 72 & 0.0094 & 0.0203 \\
\hline 73 & 0.0105 & 0.0224 \\
\hline 74 & 0.0117 & 0.0248 \\
\hline 75 & 0.0130 & 0.0274 \\
\hline 76 & 0.0146 & 0.0304 \\
\hline 77 & 0.0163 & 0.0336 \\
\hline 78 & 0.0183 & 0.0372 \\
\hline 79 & 0.0204 & 0.0409 \\
\hline 80 & 0.0226 & 0.0443 \\
\hline 81 & 0.0250 & 0.0482 \\
\hline 82 & 0.0281 & 0.0534 \\
\hline 83 & 0.0319 & 0.0600 \\
\hline 84 & 0.0363 & 0.0677 \\
\hline 85 & 0.0419 & 0.0763 \\
\hline 86 & 0.0482 & 0.0855 \\
\hline 87 & 0.0537 & 0.0948 \\
\hline 88 & 0.0590 & 0.1041 \\
\hline 89 & 0.0639 & 0.1130 \\
\hline 90 & 0.0685 & 0.1209 \\
\hline 91 & 0.0726 & 0.1273 \\
\hline 92 & 0.0763 & 0.1326 \\
\hline 93 & 0.0802 & 0.1375 \\
\hline 94 & 0.0848 & 0.1427 \\
\hline 95 & 0.0902 & 0.1478 \\
\hline 96 & 0.0978 & 0.1519 \\
\hline 97 & 0.1063 & 0.1554 \\
\hline 98 & 0.1155 & 0.1584 \\
\hline 99 & 0.1255 & 0.1591 \\
\hline 100 & 0.1364 & 0.1560 \\
\hline
\end{tabular}


O'Meara \& Bruhn | Compulsory Annuitisation 
AABFJ | Volume 7, no. 3, 2013 